\title{
RELATIONSHIP BETWEEN THE LEVEL OF KNOWLEDGE AND FAMILY SUPPORT WITH SELF-EFFICACY IN PATIENTS WITH TUBERCULOSIS
}

\author{
Made Mahaguna Putra ${ }^{1 *}$, Aditha Angga Pratama ${ }^{2}$, Ni Putu Nila Adnyani ${ }^{3}$ \\ ${ }^{1,2,3}$ School of Health Sciences Buleleng \\ *Email: md.mahagunaputra@gmail.com
}

\begin{abstract}
Introduction: Tuberculosis is a disease whose transmission rates continue to increase. Tuberculosis treatment requires support from family, level knowledge and good self-efficacy because the minimum treatment period of 6 months makes $T B$ clients need to be strengthened to be able to undergo complete treatment and successfully recover. The purpose of this study was to determine the relationship of the level of knowledge and family support with self-efficacy in tuberculosis patients at the Sawan I Community Health Center. Self-efficacy is an individual's belief in managing certain behaviors to achieve healing. Methods: This research is a correlation study with cross-sectional design. The samples used were 53 samples selected by nonprobability sampling with a purposive sampling design. The data collected through a questionnaire and obtained were tested with the Spearman rank test. From the correlation test with the Spearman rank test. Results: Correlation coefficient values indicate the relationship between knowledge and self-efficacy $(r=0.450)$ and family support with selfefficacy $(r=0.555)$, which means there is a strong and positive relationship or the better the level of knowledge and family support for TB sufferers, the better the self-efficacy of TB sufferers. Conclussions: The level of knowledge and family support are very important to maintain the self-efficacy of tuberculosis patients.
\end{abstract}

Keywords: family support; knowledge level; self efficacy; tuberculosis

\section{INTRODUCTION}

One of the infectious diseases is a problem in the world, including Indonesia is tuberculosis (TB). Tuberculosis is an infectious or infectious disease that can affect anyone and is still a health problem. Transmission of this disease through saliva splitting or sputum sufferers containing pulmonary tuberculosis bacilli (Widoyono, 2011). Indonesia is the 4th country with the highest number of tuberculosis patients in the world. The prevalence of pulmonary $\mathrm{TB}$ in Indonesia based on diagnosis is $0.4 \%$ of the population (Noviani, 2018). The number of TB sufferers in Buleleng Regency in 2017 was 699 people with the new discovery of smear TB cases (+) of 302 cases (Dinkes Kabupaten Buleleng, 2017).

The results of a preliminary study in November 2018 data on visits of pulmonary TB patients in 2018 were as many as 60 people, from the target set was 63 people with pulmonary TB. Of the 6 people interviewed 4 people had poor self-efficacy, and 4 out of 6 people had a poor understanding of the illness and lack of family support. To achieve healing is very important for patients with pulmonary TB to have knowledge about the disease. Such knowledge in terms of regularity, completeness, and compliance in taking Anti Tuberculosis Medication (OAT) (Sutrisna, 2017). Conversely, if irregular treatment will lead to treatment failure resulting in Mycobacterium Tuberculosis becoming resistant and causing cases of TB MDR (Multidrug Resistance) and will be a source of transmission for others (Zahrotul, 2012).

Research conducted by (Wijaya, 2013) that there is a significant relationship between knowledge and the activities of health cadres, where high knowledge has the possibility to be active in controlling tuberculosis cases 18 times greater than low knowledge. The family is the smallest unit of society that has a big influence on one's life. Moreover, in health, the family can play an active role in protecting a sick family member (Padila, 2012). The ability of the family to provide health care affects the health status of the family. In addition, family knowledge about health and illness also affects family behavior in resolving family health (Hendiani, 2014). Patients with pulmonary TB need more family support because family support can reduce the psychological burden. Based on the description above, it can be seen that there are still many pulmonary tuberculosis patients who have less knowledge and lack of family support, therefore researchers are interested in conducting research into the relationship between the level of knowledge and family support with self-efficacy in patients with pulmonary tuberculosis in the working area of the Sawan I Public Health Center, Buleleng Bali. 
Table 1 Characteristics of respondents $(n=53)$

\begin{tabular}{|c|c|c|}
\hline Characteristics of respondents & $\mathrm{n}$ & $\%$ \\
\hline \multicolumn{3}{|l|}{ Gender } \\
\hline Male & 31 & 58.5 \\
\hline Female & 22 & 41.5 \\
\hline \multicolumn{3}{|l|}{ Age } \\
\hline \multicolumn{3}{|l|}{$\operatorname{Min}(21$ th $)$} \\
\hline \multicolumn{3}{|l|}{$\operatorname{Max}$ (73th) } \\
\hline \multicolumn{3}{|l|}{ Mean $(49,85)$} \\
\hline \multicolumn{3}{|l|}{ Education Level } \\
\hline Primary school & 16 & 30.2 \\
\hline Junior high school & 27 & 50.9 \\
\hline Senior high school & 7 & 13.2 \\
\hline College & 3 & 5.7 \\
\hline \multicolumn{3}{|l|}{ Job } \\
\hline Labor & 15 & 28.3 \\
\hline Government employees & 3 & 5.7 \\
\hline Entrepreneur & 18 & 34.0 \\
\hline Does not work & 17 & 32.1 \\
\hline \multicolumn{3}{|l|}{ Knowledge level } \\
\hline Good & 40 & 75.5 \\
\hline Less & 13 & 24.5 \\
\hline \multicolumn{3}{|l|}{ Family Support } \\
\hline Low & 10 & 18.9 \\
\hline Moderate & 17 & 32.0 \\
\hline High & 26 & 49.1 \\
\hline \multicolumn{3}{|l|}{ Self Efficacy } \\
\hline Low & 8 & 15.1 \\
\hline Moderate & 17 & 32.1 \\
\hline High & 28 & 52.8 \\
\hline
\end{tabular}

Table 2 Cross-tabulation of knowledge Levels and family support with Self Efficacy

\begin{tabular}{|c|c|c|c|}
\hline Variable & Low Self Efficacy & Medium Self Efficacy & High Self Efficacy \\
\hline \multirow{2}{*}{ Lack of Knowledge } & 3 & 5 & 5 \\
\hline & $5.7 \%$ & $9.4 \%$ & $9.4 \%$ \\
\hline \multirow{2}{*}{ Good Knowledge Level } & 5 & 12 & 23 \\
\hline & $9.4 \%$ & $22.6 \%$ & $43.4 \%$ \\
\hline \multirow{2}{*}{ Low Family Support } & 4 & 2 & 4 \\
\hline & $7.5 \%$ & $3.8 \%$ & $7.5 \%$ \\
\hline \multirow{2}{*}{ Medium Family Support } & 4 & 8 & 5 \\
\hline & $7.5 \%$ & $15.1 \%$ & $9.4 \%$ \\
\hline \multirow{2}{*}{ High Family Support } & 0 & 7 & 19 \\
\hline & $0 \%$ & $13.1 \%$ & $35.8 \%$ \\
\hline \multicolumn{4}{|c|}{ Table 3 Relationship Analysis of Knowledge Level, Family Support with self-efficacy } \\
\hline \multirow{2}{*}{\multicolumn{2}{|c|}{ Variable }} & \multicolumn{2}{|c|}{ Self-efficacy } \\
\hline & & $\mathrm{r}$ & $\mathrm{p}$ \\
\hline Knowledge level & & 0.450 & 0.001 \\
\hline Family support & & 0.555 & 0.000 \\
\hline
\end{tabular}




\section{METHODS}

This study was used to cross sectional design, which is the subject of research should be observed on the day or at the same time (Nursalam, 2014). The independent variable is the level of knowledge and family support while the dependent variable is self-efficacy, the measuring instrument used is a questionnaire sheet with a sample size of 53 people. This study uses purposive sampling with inclusion criteria: a) Patients who are taking pulmonary TB treatment, b). Lung TB patients with a minimum age of 12 years, c). Willing to be a respondent and d). Lung TB patients who have a family. Questionnaire The level of knowledge consists of 18 questions ( $\mathrm{r}$ $=0.361, \alpha=0.989$ ). The family support questionnaire consisted of 12 questions ( $\mathrm{r}=$ $0.481, \quad \alpha=0.950)$. The self-efficacy questionnaire consisted of 10 questions ( $\mathrm{r}=$ 0.496, $\alpha=0.872$ ). This research was conducted at the Sawan I Community Health Center, Buleleng Regency, Bali. This research was conducted in May-June 2019. The statistical test used is the Spearmen rank correlation test which is used to determine the relationship between two or more variables that are ordinal scale (Sugiyono, 2017). Respondents involved in this study had already been given an explanation of the research. This study has passed the ethical test by the Health Research Ethics Committee of the Buleleng College of Health Sciences with no: 051 / ECKEPK-SB / V / 2019.

\section{RESULTS}

Based on table 1. It is known that most respondents are male and a small proportion is female. Respondents with the lowest age are 21 years and the highest age is 73 years. Most respondents with junior high school education and the least respondents who graduated from college. Most respondents have jobs as entrepreneurs and at least work as civil servants. Most respondents have a good level of knowledge and a small proportion have a bad level of knowledge. Most respondents with high family support and the least with low family support. Self-efficacy that most respondents have is high self-efficacy and the least is low self-efficacy.

Based on the table 2, it can be seen that most respondents experience a good level of knowledge and high self-efficacy. The least experienced a low level of knowledge and low self-efficacy. Based on the table above, it can be seen that from the total of 53 respondents studied, the insight was that most respondents had high family support and high self-efficacy. The remaining few experienced low family support and moderate self-efficacy.

From the table 3, the results of the analysis of the spearman rank test can be seen from the p-value (0.001) which means $\mathrm{p}<0.05$, it can be concluded that there is a strong significant relationship between the variable level of knowledge with the variable selfefficacy. Correlation coefficient 0.450 which means the correlation is strong enough and positive value indicates the nature of the direction of the relationship. Spearman rank test analysis results can be seen from the pvalue that is $(0,000)$ which means $p<0.05$, it can be concluded that there is a significant and strong relationship between family support variables and self-efficacy variables. Correlation coefficient 0.555 which means a strong correlation and a positive value indicates the nature of the direction of the relationship.

\section{DISCUSSIONS}

Based on the results of the study it was found that the average age of the respondents was 49.85 years. This shows that pulmonary TB mostly affects adults. In accordance with research conducted by (Herawati, 2015) the results of the study showed that pulmonary TB disease was mostly found at the productive age of 15-55 years because that age had a lot of interaction or socializing with other people or the surrounding environment (Fitri Maulidia, 2014). Most respondents who experienced pulmonary tuberculosis were male. In accordance with research conducted by (Prasetya, 2015) the results of the study showed that the majority of male respondents and a small proportion of respondents were female $(36.0 \%)$. this is due to smoking habits in men. Smoking is predicted as a significant factor causing differences in the proportion of sexes in the incidence of pulmonary TB (Dewi, 2014).

Researchers found that of the 53 respondents surveyed, the majority were junior high school graduates and many respondents who had a low educational background. Based on research conducted by (Noorratri, 2016) 
this study shows that education greatly influences pulmonary tuberculosis patients in terms of treatment, low education is a factor that affects non-compliance with taking the medication in pulmonary TB patients. Most respondents with pulmonary TB come from labor and entrepreneurial occupations. People who work have a high burden, both physical and mental burdens. In line with research conducted by (Noorratri, 2016) the results of the study stated that people who work less rest than people who do not work. Work will also affect one's income and high-income people tend to pay more attention to their health (Rajeswari et al., 2009). Supported research by (Nair et al 2007) with the results of the study that the majority of people with pulmonary tuberculosis with a low economy.

Most respondents with a good level of knowledge and high self-efficacy, the least with a level of lack of knowledge and low selfefficacy. From the results of the analysis which means that it can be concluded that there is a significant relationship between the level of knowledge with self-efficacy in patients with pulmonary tuberculosis in the working area of the Sawan I Public Health Center, which is conducted by (Octavia, 2017) From this research it was found that there was a significant relationship between knowledge and self-efficacy of pulmonary TB. This is due to the non-formal education they have received so far, namely counseling and counseling from public health center staff. Respondents with a good level of knowledge and low self-efficacy, this is because respondents who feel bored and desperate with treatment. Although respondents know that by taking medicine regularly they can recover but some of the respondents are not sure because of the length of treatment and the side effects of the drugs they feel. They say that they have been taking drugs for months but have not healed, in fact the side effects of the drug make them uncomfortable and very disturbed. In addition there are also those who say they do not have the support of their families, none of them take treatment for reasons of work and are too busy with themselves so that $\mathrm{TB}$ patients receive less attention from family members. In contrast with respondents whose level of knowledge is lacking and self-efficacy is high, it is because there is motivation from within the patient, besides the trust and family support that the patient has made him confident that he can recover.

Based on the results of research on the relationship of family support with selfefficacy in patients with pulmonary tuberculosis in the work area of the Sawan I Health Center, it was found that from all respondents totaling 53 people. Most respondents with high family support and high self-efficacy, at least with low family support and moderate self-efficacy. Furthermore, an analysis test was performed, which means there is a significant relationship between family support and self-efficacy in the work area of the Sawan I Community Health Center. This is supported by research conducted by (Hendiani, 2014) with the results of the study note that family support as a supervisor swallowing drugs is one of the factors that influence self-efficacy. Optimal family support can increase a patient's desire to recover and undergo treatment properly (Ganes, 2012). In line with research conducted by (Maratus, 2018) which states there is a significant relationship between family support and selfefficacy of patients with pulmonary tuberculosis. From research conducted by researchers shows that there is a significant relationship between the level of knowledge and self-efficacy, as well as the relationship of family support and self-efficacy, with a direct relationship shows that most respondents have a good level of knowledge, high family support, and high self-efficacy.

According to family researchers can be a source of social support for other family members in solving health problems. Patients with pulmonary TB need more family support because family support can reduce the psychological burden. If family support is fulfilled, it will increase the confidence of pulmonary TB sufferers, so that patients have the confidence to recover and take medication regularly to maintain endurance so that physical condition does not decrease. Family support such as accompanying TB patients in treatment to health services, families provide assistance in taking drugs and provide financial support in the form of transportation costs to health services. This is supported by a statement from (Hendiani, 2014) that family support is in the form of concrete support, emotional support, information support, and appreciation support. Family support is very important especially in patients with chronic 
diseases. Family support for pulmonary TB sufferers can encourage patient recovery. Moreover, its role as a supervisor to swallow drugs, the family must encourage the healing of sufferers well.

\section{CONCLUSIONS}

Most respondents with a good level of knowledge. Respondents with pulmonary tuberculosis have good knowledge, although the average respondent has a junior high school education they have good knowledge about the disease. The family can be a source of social support for other family members in solving health problems. Patients with pulmonary TB need more family support because family support can reduce the psychological burden.

\section{REFERENCES}

Dewi, G. I. (2014). Hubungan Antara Pengetahuan, Sikap Pasien dan Dukungan Keluarga dengan Kepatuhan Minum Obat Pada Pasien TB Paru. Di Wilayah Kerja Puskesmas Jatibarang Kecamatan Jatibarang Kabupaten Indramayu Http://Www.Depkes.Go.Id/Downloa Ds/Profil/Prov\%20jateng\%20200 6.Pdf, Diperoleh 2 Mei 2014.

Dinkes Kabupaten Buleleng. (2017). Profil Kesehatan Buleleng. Buleleng: Dinas Kesehatan Kabupaten Buleleng.

Fitri Maulidia, D. (2014). Kepatuhan Minum Obat Pada Penderita Tuberkulosis.

Ganes, C. (2012). The Relationship Between Perceived Family Support As Drug Consumption Controller and Self Efficacy Of Tuberculosis Patients, 1 .

Hendiani, N. et al. (2014). Hubungan antara persepsi dukungan keluarga sebagai pengawas minum obat dan efikasi diri penderita tuberkolosis di bkpm semarang. Fakultas Psikologi Universitas Diponegoro Jurnal Psikologi Undip, 13, 84.

Herawati, E. (2015). Hubungan Antara Pengetahuan dengan Efikasi Diri Penderita Tuberkulosis Paru di Balai Kesehatan Paru Masyarakat Surakarta. Publikasi Ilmiah, 02(XV), 3-12.

Maratus, M. (2018). Hubungan Dukungan
Keluarga dengan Efikasi Diri Klien Tuberkulosis Paru di wilayah kerja Puskesmas Jakarta Selatan. Motorik, 13(27), 1-5.

Nair, D. M., George, A., \& Chack, K. T. (2007). Tuberculosis New Insights From Poor Urban Patients, 12(1), 77-85.

Noorratri, E. (2016). Faktor Yang Mempengaruhi Efikasi Diri Pada Pasien TB Paru. Journal Ilmiah Keperawatan Dan Kesehatan Journal of Nursing and Health (JNH), 2(1), 1-7.

Noviani, W. (2018). Hubungan Tingkat Stres dengan Efikasi Diri Pada Pasien TB paru di Wilayah Kerja Puskesmas Patrang Kabupaten Jember.

Nursalam. (2014). Metode Penelitian Ilmu Keperawatan (Edisi III). Jakarta: Salemba Medika.

Octavia, D. (2017). Hubungan Pengetahuan, Persepsi, Self Efficacy dan Pengaruh Interpersonal Terhadap Pencegahan Penularan TB Paru, 6(2).

Padila. (2012). Keperawatan Keluarga. Nuha Medika.

Prasetya, H. (2015). Hubungan Pengetahuan dan Motivasi Pasien TBC dengan Kepatuhan Berobat Pasien TBC. UPT Puskesmas Mantup Kabupaten Lamongan Niven, 2(XV), 33-38.

Rajeswari, R., Balasubramanian, R., Muniyandi, M., Geetharamani, S., Thresa, X., \& Venkatesan, P. (2009). Socio-economic Impact Of Tuberculosis On Patients and Family In India, 3(November 1998), 869-877.

Sugiyono, P. D. (2017). Statistika Untuk Penelitian. Bandung: Alfabeta.

Sutrisna, A. A. (2017). Hubungan efikasi diri dengan kepatuhan minum obat penderita tuberkulosis paru di rumah sakit paru respira yogyakarta, 02(XV), 61-73.

Widoyono. (2011). Penyakit Tropis (Epidemiologi, Penularan, Pencegahan \& Pemberantasannya). Jakarta: Erlangga.

Wijaya, K. et al. (2013). Hubungan Pengetahuan, Sikap dan Motivasi Kader Kesehatan dengan Aktivitasnya Dalam Pengendalian Kasus Tuberkulosis Paru, 1(1), 38-48.

Zahrotul, I. (2012). Risk Factor Of Multi Drug Resistant Tuberculosis, 8(1), 60-66. 